\title{
Sosialisasi dan Partisipasi Masyarakat dalam Program Pemberdayaan Masyarakat Kelurahan (PPMK) di Kelurahan Klender
}

\author{
The Community Participation and Socialization in \\ Empowering Program (PPMK) at Klender Village
}

\author{
Defina $^{1}$ \\ ${ }^{1}$ Dosen Mata Kuliah Dasar Umum Institut Pertanian Bogor
}

Abstract

\begin{abstract}
Village community empowerment program (PPMK) aims to overcome poverty. Socialization of the programs to the community is one of the factors that can determine the participation of the community. Obtaining a description of socialization and community involvement is the purpose of this paper. The description of community participation in PPMK that was presented by Adi was analyzed with the definition of participation (community involvement in problem identification, decision-making process to solve problem, implementation of the result and evaluation on a development activity). This paper will also present the percentage of public knowledge about the program and the percentage of community involvement in the program.
\end{abstract}

Key word: poverty, empowerment, participation

Abstrak

Program pemberdayaan masyarakat kelurahan (PPMK) bertujuan mengatasi kemiskinan. Sosialisasi program ke masyrakat salah satu faktor penentu partisipasi masyarakat. Untuk memperoleh gambaran sosialisasi dan keterlibatan masyarakat menjadi tujuan tulisan ini. Gambaran partisipasi masyarakat pada PPMK dianalisis dengan definisi partisipasi yang dikemukan oleh Adi yaitu keterlibatan masyarakat dalam pengidentifikasiaan masalah, proses pengambilan keputusan untuk mengatasi masalah, pelaksanaan hasil keputusan dan evaluasi pada suatu kegiatan pembangunan. Dalam tulisan ini juga akan dilihat persentase pengetahuan masyarakat tentang program dan persentase keterlibatan masyarakat dalam program.

Kata Kunci: kemiskinan, pemberdayaan, partisipasi

\section{Pendahuluan}

Jakarta dengan luas $650 \mathrm{~km}^{2}$ memiliki jumlah penduduk 11 juta jiwa. Menurut data BPS DKI Jakarta tahun 2000, jumlah penduduk miskin di Jakarta sebanyak 80 ribu KK atau 370 ribu jiwa. Meskipun jumlah penduduk miskin ini hanya beberapa persen dari jumlah penduduk miskin di Indonesia, yakni 37 juta jiwa, tetap harus menjadi perhatian dalam pembangunan. Angka ini terus bertambah pada tahun 2004, yakni berdasarkan data yang dikeluarkan Badan Pusat Statistik Provinsi DKI Jakarta, penduduk miskin Jakarta berjumlah 370.898 jiwa dengan 91.468 rumah tangga miskin. Angka ini menunjukkan peningkatan $17 \%$ dari tahun sebelumnya. Jika dibandingkan dengan total penduduk Jakarta pada tahun yang sama, persentase penduduk miskin adalah $10 \%$. Jumlah penduduk miskin di Jakarta menyebar. Daerah yang banyak penduduk miskinnya adalah Jakarta Utara dan Jakarta Timur, mencapai ratusan ribu (Kompas Cyber Media, 21 April 2005).

Meskipun Pemerintah Daerah Khusus Ibu Kota
Jakarta terus membangun, masih banyak rakyat hidup miskin. Pemerintah Khusus Ibu Kota Jakarta selama ini telah berusaha membuat berbagai program untuk menanggulangi masalah kemiskinan. Meskipun telah banyak program yang dilakukan oleh pemeritah DKI Jakarta khususnya dan Indonesia umumnya untuk mengatasimasalahkemiskinan, dalam realisasinyamasih ditemukan kelemahan, terutama sekali masih belum optimalnya partisipasimasyarakat. Hal ini bisa dilihat dari apa yang diungkapkan Kusuma (Jurnal Analisis Sosial, 2002: 182), bahwa pelaksanaan P2KP masih lemah, khususnya dalam upaya mensosialisasikan program. Begitu juga dengan kegiatan Program Pengembangan Kecamatan (PPK), partisipasi masyarakat tidak terlalu tinggi. Menurut Sumarto (2004: 115-116), tingkat partisipasi pada Program Pengembangan Kecamatan adalah sedang. Pada proses perumusan rencana PPK, terlihat partisipasi dari kelompok miskin dan marginal. Namun pada pelaksanaan kegiatan, partisipasi masyarakat miskin dan perempuan masih kurang dan kebanyakan masih menggantungkan pada konsultan pemerintah. Sementara itu, untuk program yang 
sama (PPK), Widodo (Jurnal Analisis Sosial, 2002: 168) melihat bahwa program ini belum berkelanjutan sehingga untuk tercapainya tujuan belum maksimal. Begitu juga partisipasi masyarakat dalam Forum Komunitas Perencana Pembangunan, meskipun sudah ada, tapi menurut Hasibuan dalam kesimpulan tesisnya (2003: 203) masih sebatas diskusi atau konsultasi. Dalam forum tersebut, aspirasi rakyat untuk ikut aktif dalam perencanaan pembangunan belum maksimal. Menurut Zulhaeni (2003: 249) partisipasi masyarakat tidak maksimal dalam forum warga karena lebih dikuasai oleh lurah. Di sisi lain, Widiantoro dalam tesisnya yang membahas tentang Program Penanggulangan Kemiskinan di Perkotaan (P2KP) di Kelurahan Condong Catur, Kecamatan Depok, Kabupaten Sleman, Yogyakarta (2003: 252), partisipasi masyarakat dalam program masih diabaikan.

Dari paparan di atas, penelitian ini melihat bahwa program-program selama ini belum didukung oleh masyarakat sepenuhnya. Keterlibatan masyarakat masih belum optimal dan juga sosialisasi program belum maksimal. Hal ini secara tidak langsung akan memengaruhi pelaksanaan suatu program dan hasil yang akan dicapai. Hal ini bisa dilihat salah satunya dari kenyataan bahwa sejak krisis moneter (1997) melanda Indonesia, program yang dicanangkan pemerintah untuk menanggulangi masalah kemiskinan banyak, namun penduduk miskin tetap masih banyak. Melihat kondisi tersebut dan dengan diberlakukannya Otonomi Daerah, maka Pemerintah Daerah Khusus Ibu Kota Jakarta, sejak tahun 2001 telah melaksanakan Program Pemberdayaan Masyarakat Kelurahan (PPMK).

PPMK menekankan adanya partisipasi dari masyarakat. Penekanan ini terlihat pada prinsip yang digunakan, salah satunya adalah partisipasi masyarakat. Jadi, PPMK memberikan peranan yang lebih besar kepada masyarakat untuk merencanakan, melaksanakan dan mengawasi serta diharapkan dapat meningkatkan partisipasi masyarakat, baik dalam bentuk pemikiran, tenaga maupun finansial. Namun, yang menjadi pertanyaan dalam tulisan ini adalah: (1) Bagaimana sosialisasi program? (2)Apakah masyarakat mengetahui program dan berapa persen? (3) Bagaimana partisipasi masyarakat dalam PPMK dalam bentuk apa saja, serta apakah dari awal sampai akhir? (4) Bagaimana persentase partisipasi masyarakat itu? Adapun tujuan penulisan ini adalah: (1) Mendeskripsikan sosialisasi program; (2) Mendeskripsikan dan menghitung persentase pengetahuan masayrakat tentang PPMK; (3) Mendeskripsikan partisipasi masyarakat; (4) Menghitung persentase partisipasi masyarakat dalam PPMK.

\section{Metode Penelitian}

Penelitian ini bertujuan untuk menghitung dan menjelaskan pengetahuan masyarakat tentang PPMK dan partisipasi masyarakat. Oleh karena itu, pada penelitian ini pendekatan yang digunakan adalah gabungan pendekatan kuantitatif dan kualitatif. Pendekatan kualitatif dapat memberikan gambaran yang mendalam mengenai keadaan atau kondisi objek yang akan diteliti. Gambaran ini diperoleh melalui wawancara yang mendalam terhadap informan. Sedangkan metode kuantitatif untuk melihat kuantitas partisipias dan pengetahuan masyarakat. Bogdan dan Taylor dalam Moleong (2000:3) mendefinisikan "metodologi kualitatif" sebagai prosedur penelitian yang menghasilkan data deskriptif berupa kata-kata tertulis atau lisan dari orang-orang dan perilaku yang dapat diamati. Sementara Lofland (1984) dalam Moleong (2000:112) mengatakan bahwa kata-kata dan tindakan merupakan sumber data utama dalam penelitian ini. Sedangkan selebihnya adalah data tambahan. Penelitian ini dilakukan dengan cara terjun langsung ke lapangan untuk meneliti objek kajian. Dalam hal ini untuk memperoleh informasi yang mendalam dengan cara berinteraksi langsung dengan masyarakat

Pada penelitian ini pemilihan informan dilakukan dengan menggunakan teknik bola salju (Snowball Sampling). Jumlah informan awalnya sedikit dan akhirnya menjadi banyak. Penarikan sampel bola salju ini mempunyai beberapa tahap. Pertama, menentukan responden awal yang akan diwawancarai. Kedua, setelah ada responden awal tersebut, akan diperoleh responden lainnya berdasarkan petunjuk responden awal. Ketiga, hal ini dilakukan terus sampai diputuskan bahwa jumlah responden sudah cukup. Pengumpulan data dilakukan dengan tiga tahap, yaitu: studi kepustakaan, observasi dan interviu.

\section{Hasil dan Pembahasan}

Kelurahan Klender merupakan salah satu kelurahan yang terpilih dari 25 kelurahan di DKI 
Jakarta (masing-masing kota mendapatkan lima kelurahan) sebagai pilot project. Sebagai salah satu pilot project, Kelurahan Klender memperoleh bantuan dana sebesar Rp 2 miliar pada tahun 2001. Dana Rp 2 miliar ini digunakan untuk tribina, yaitu: 50\% bina ekonomi sebanyak Rp 1 miliar, 25\% senilai Rp 500 juta untuk bina sosial dan $25 \%$ lagi untuk bina fisik. Pembagian ini berdasarkan keputusan Badan Perencanaan Kota Jakarta Timur. Ketika terjadi banjir pada tahun 2002, pemerintah DKI Jakarta memberikan perhatian kepada masyarakat dengan melaksanakan PPMK di kelurahan lainnya di Jakarta. Sementara itu, 25 kelurahan yang menjadi pilot project tidak diberi dana lagi, tetapi mereka harus mengambil dana dari bina fisik atau sosial untuk dialokasikan ke bina ekonomi. Berdasarkan hasil musyawarah Dekel dengan RW nya masing-masing, akhirnya Dekel Klender mengalokasikan 50\% dari dana bina sosial yang telah dialokasikan sebelumnya ke bina ekonomi.

Hal ini dilakukan untuk membantu ekonomi masyarakat yang terkena banjir, sehingga usaha mereka bisa hidup kembali. Jadi, dari Rp 2 miliar yang dialokasi Kelurahan Klender, sebanyak $\mathrm{Rp}$ 1,25 miliar untuk bina ekonomi. Kelurahan Klender kembali mendapatkan kucuran dana pada tahun 2004 dan tahun 2005. Tahun 2004, dana yang dialokasikan ke Kelurahan Klender sebesar Rp 250 juta. Dari jumlah tersebut, Dekel Klender mengalokasikan Rp 20 juta (sesuai dengan pedoman pelaksanaan PPMK) untuk biaya operasional. Sisa dana tersebut hanya untuk bina sosial dan fisik, masing-masing Rp 104 juta dan Rp 126 juta. Hal ini sesuai dengan intruksi dari pemerintah Kota Jakarta Timur. Sedangkan pada tahun 2005, Kelurahan Klender mendapatkan bantuan sebesar Rp 1,195 miliar. Setelah dikeluarkan biaya operasional Rp 20 juta, dana tersebut baru dibagi, yaitu $\mathrm{Rp} 705$ juta untuk bina ekonomi dan masingmasing Rp 235 juta untuk bina sosial dan bina fisik.

Sebelum dana PPMK dicairkan pertama kalinya, yaitu pada Oktober 2001, di Kelurahan Klender dibentuk Dewan Kelurahan. Anggota Dewan Kelurahan ini adalah mereka yang terpilih di RW nya masing-masing melalui musyawarah. Dewan Kelurahan Klender yang berjumlah 18 orang (sesuai dengan jumlah RW di Kelurahan Klender) dilantik pada bulan April 2002. Setelah Dewan Kelurahan dibentuk, barulah dibentuk TPK, UPK dan forum warga di masing-masing RW. Pemben-ukan TPK
RW ini pun dengan musyawarah, yakni setiap RT di masing-masing RW mengirimkan dua orang utusan untuk duduk di TPK RW. TPK dan UPK RW yang telah terbentuk di 18 RW diberikan pelatihan selama lima hari di Cisarua. Materi pelatihan berkaitan dengan cara pelaksanakan PPMK, seperti: pembuatan proposal bina fisik dan bina ekonomi. Jadi, TPK dan UPK RW bisa membantu masyarakat untuk membuat proposal bina ekonomi dan bina fisik.

Setelah dibentukan lembaga yang akan melaksanakan di tingkat RW, sosialisasi dilanjutkan ke masyarakat. Sosialisasi ini dilakukan oleh lembaga yang telah dibentuk, yaitu TPK/UPK RW dibantu oleh Dewan Kelurahan (Dekel) RW, dan pengurus RW. Sosialisasi ke warga dimulai di tingkat RW dan dilanjutkan di tingkat RT. Sebelum suatu program dilaksanakan pada suatu wilayah tertentu, diperlukan sosialisasi awal. Sosialisasi ini dilakukan tidak hanya kepada tokoh atau pemuka masyarakat, tetapi juga dilakukan untuk masyarakat. Begitu juga halnya dengan PPMK, sosialisasi juga haruslah gencar ke masyarakat agar program ini terlaksana dengan baik.

Dari hasil wawancara dengan Sekretaris Lurah Klender, Ketua Dekel dan beberapa anggota Dekel, 8 orang tokoh masyarakat (RT, RW, mantan ketua RW, TPK/UPK RW) dan LSM pendamping mereka mengatakan bahwa sosialisasi dilakukan dan sistem berjenjang. Sosialisasi dimulai di tingkat kelurahan dengan mengundang RT, RW, dan tokoh masyarakat. Sosialisasi dilanjutkan di tingkat RW dengan dibentuknya TPK (Tim Pelaksana Kegiatan)/ UPK serta forum warga. Selanjutnya, sosialisasi dilanjutkan di tingkat RT, yaitu pada pertemuan bulanan RT. Hal ini juga sesuai dengan hasil wawancara dengan Sekretaris Lurah Klender.

Sosialisasi program dilaksanakan 2-3 kali untuk masing-masing RW. Sosialisasi dilakukan oleh utusan RW yang menjadi anggota Dewan Kelurahan (Dekel) Klender, TPK RW dan LSM pendaping. Sosialisasi kepada atokoh masyarakat dilakukan dengan mengundang mereka untuk menghadiri sosialisasi di kelurahan. Sementara itu, untuk anggota Dekel, sosialisasi dilaksanakan selama 5 hari yakni melalui pelatihan penguatan kelembagaan Dekel.

Hal senada juga dikatakan Direktur LSM Lembaga Pengkajian Pengembangan Sosial Ekonomi (LPPSE). Menurutnya, sosialisasi dilakukan secara berjenjang, yaitu dari Kota Jakarta Timur, dilanjutkan ke tingkat kecamatan dan kelurahan. 
Setelah itu, dilakukan sosialisasi ke RW, RT, dan tokoh masyarakat. Setelah dibentuk TPK/UPK di tingkat RW, sosiliasi lebih gencar dilakukan oleh TPK/ UPK bersama LSM, RW, Dekel RW dan RT ke masyarakat. Sebelum program dilaksanakan, sosialisasi pertama ke masyarakat dilakukan oleh UI (Universitas Indonesia). Namun, sosialisasi ini hanya bersifat umum dan tidak berkesinambungan sehingga tidak semua warga mengetahui. Akan tetapi, setelah ada kerja sama dengan LSM, sosialisasi kembali dilaksanakan dan lebih sering serta sampai ke semua warga. Sosialisasi di tingkat warga langsung dilaksanakan oleh RT dan gabungan beberapa RT.

Dari uraian tersebut sebelumnya terlihat bahwa Sekretaris Lurah, LSM, Dekel, dan tokoh masyarakat kelurahan Klender menyatakan bahwa sosialisasi bertingkat dan telah menjangkau masyarakat. Akan tetapi, ketika hal ini ditanyakan ke warga, dari 25 orang yang diwawancarai, hanya tujuh orang (28\%) yang mengetahui PPMK. Ada dari mereka yang mengetahui PPMK setelah satu tahun prog-ram ini terlaksana. Hal tersebut dapat dilihat dari kutipan di bawah ini:

Terus terang saya tidak tahu apa itu PPMK. Setelah satu tahun PPMK berjalan, baru saya tahu ada PPMK. Saya pun tahu dari teman-teman yang menjadi pemanfaat program. Yang saya tahu PPMK adalah suatu program peminjaman modal dari pemerintah. (Ded, RT/RW 01/15, Sep. 2005).

Mereka yang menyatakan bahwa mereka mengatahui PPMK, ternyata mereka pun hanya mengetahui bahwa ada pinjaman bergulir dari kelurahan. Dari 25 orang yang diwawancarai itu, hanya dua orang $(8 \%)$ menyatakan bahwa mereka mengatahui PPMK. Mereka mengetahui bahwa PPMK suatu program tribina (fisik, sosial, ekonomi) untuk menanggulangi kemiskinan. Kedua warga tersebut mengetahui karena satu orang sering membaca di koran dan satu orang lagi karena sering mengikuti rapat bulanan di RT. Hal itu dapat di lihat dari kutipan di bawah ini:

Saya mengetahuinya melalui rapat yang diadakan RT. Saya selalu hadir setiap arisan bulan RT. Pertemuan bulan itu

\begin{abstract}
membicarakan permasalahan yang dihadapi warga dan informasi dari pertemuan RW. Permasalahan yang dibahas tidak hanya masalah sosial, tetapi juga fisik dan lingkungan, seperti saluran air yang tersumbat dan jalan yang tidak bagus. Saya juga memberikan usulan kursus untuk bina sosial. (Am, RT/RW 01/03, Nov. 2005).
\end{abstract}

Untuk lebih jelasnya partisipasi masyarakat dalam PPMK di Kelurahan Klender, di bawah ini akan diuraikan lebih rinci. Uraian di bawah ini berdasarkan tujuan penelitian, yaitumendeskripsikan partisipasi masyarakat dan menghitung persentase partisipasi masyarakat pada PPMK. Partisipasi pada PPMK tersebut diuraikan dalam empat tahap, yaitu: tahap assessment, perencanaan, pelaksanaan dan evaluasi dari tahun 2001-2005, dan pada tiga bina (sosial, ekonomi, fisik).

\section{Bina Sosial}

\section{Gambaran Partisipasi Masyarakat pada Tahap Assessment}

Berdasarkan informasi yang diperoleh dari warga, pengurus RT, RW/TPK RW dan Dekel melakukan pengidentifikasian masalah (assessment) secara bertahap. Assessment dilaksanakan setiap dana bina sosial akan dicairkan. Dekel Klender mulai aktif pada bulan Agustus 2001 karena baru dilantik pada bulan April 2001. Agar tahun anggaran 2001 bisa dimanfaatkan, Dekel memfokuskan pada bina ekonomi. Jadi, bina sosial belum diidentifikasi dan direncanakan.

Identifikasi masalah sosial baru dilakukan pada tahun 2002. Identifikasi ini dilakukan secara bertahap. Tahap pertama adalah dilakukan untuk tingkat komunitas lebih kecil, yaitu rukun tetangga (RT). Tahap kedua adalah pada komunitas yang lebih besar yaitu rukun warga (RW). Sedangkan tahap terakhir adalah tahap pada komunitas lebih besar atau di tingkat lokal, yaitu kelurahan.

Di tingkat RT, assessment dilakukan pada pertemuan bulanan warga. Pertemuan ini dikenal dengan arisan bulanan RT. Pada umumnya semua kepala keluarga (KK) menjadi anggota arisan. Meskipun semua KK menjadi anggota arisan, tidak semua KK (tidak mesti harus kepala keluarga, 
bisa utusan keluarga) yang hadir pada setiap pertemuan tersebut. Pertemuan itu, menurut Sla, mantan pengurus RT 06 RW 03 yang sekarang menjabat sebagai TPK/UPK RW 03, dihadiri oleh tiga perempat atau setengah dari KK. Bahkan, menurutnya, kadang-kadang KK yang hadir tidak cukup setengah dari jumlah KK yang ada di RT dan KK yang hadir pun bergantian. Pada pertemuan tersebut, utusan KK melakukan pengidentifikasian masalah yang ada. RT hanya memfasilitasi saja. Pada pertemuan ini masyarakatlah yang aktif untuk mengungkapkan permasalahan sosial yang selama ini dirasakan ataupun dilihat. Di akhir pertemuan tersebut mereka mengumpulkan semua permasalahan yang ada.

Permasalahan yang sudah dibahas oleh masyarakat di tingkat RT dibahas lagi pada komunitas lebih luas (RW). Pertemuan RW juga dilaksanakan sekali sebulan. Utusan RT (dalam hal ini biasanya pengurus RT) menyampaikan apa yang sudah dibicarakan atau dibahas pada pertemuan RT mereka masing-masing. Pertemuan ini dilaksanakan secara bergiliran. Seperti RW 03, menurut Sla (mantan Ketua RT 06) dan Mar (Ketua RT 12 RW 03), RW ini memiliki 15 RT. Jadi, pertemuan pertama dilaksanakan di RT 01, pertemuan kedua di RT 02, dan begitu seterusnya.

Pertemuan komunitas lebih besar adalah pertemuan forum warga. Pertemuan ini menurut Ketua Dekel (April 2006) difasilitasi oleh Lurah dan LSM. Pertemuan ini dihadiri oleh utusan RT, RW, tokoh masyarakat, TPK/UPK RW, organisasi masyarakat (seperti Karang Taruna dan PKK) dan pengurus Dekel Klender. Pada pertemuan forum warga di kelurahan pada bulan Juni 2002 di aula kelurahan, masing-masing utusan warga sudah memiliki data kondisi sosialnya. Menurut Sub (Ketua Dekel), Say (Ketua RW 01) dan Sla (TPK/UPK RW 03), pada pertemuan tersebut, peserta pertemuan menyampaikan permasalahan yang telah diidentifikasi di wilayahnya. Hal ini disampaikan oleh utusan warga atau RT nya masingmasing. Setelah setiap utusan RT menyampaikan permasalahan yang mereka temui di wilayahnya, selanjutnya mengurutkan masalah keseluruhannya untuk menjadi permasalahan tingkat kelurahan.

Berdasarkan informasi yang diberikan oleh Sub (Ketua Dekel) dan laporan pertemuan forum warga, hasil identifikasi bidang sosial pada tahun 2002 adalah masih banyaknya jumlah penduduk miskin, narkoba, anak putus sekolah dan pengangguran. Namun, pertemuan tingkat kelurahan ini hanya terlaksana satu kali dari tahun 2001-2005.

Pengidentifikasikan masalah atau pemetaan masalah sosial baru dilaksanakan kembali pada tahun 2004 dan 2005. Hal ini disebabkan anggaran hanya cair pada tahun tersebut. Pada tahun 2003, Kelurahan Klender tidak mendapatkan alokasi dana PPMK. Pengidentifikasian masalah ini pun hanya dilaksanakan di tingkat RT dan RW. Sama halnya pada tahun 2002, pada tahun anggaran 2004 dan tahun anggaran 2005, masyarakat berpatisipasi dengan hadir pada pertemuan tingkat RT dan menyampaikan masalah sosial yang mereka rasakan.

\section{Gambaran Partisipasi Masyarakat pada Tahap Perencanaan}

Setelah dilakukan identifikasi masalah pada bina sosial, mereka difasilitasi untuk mencari pemecahan masalah sosial yang ada. Pada pertemuan tingkat RT, mereka melakukan diskusi untuk memecahkan masalahan tersebut. Setiap permasalahan sosial yang telah dibahas pada tahap assessment diurutkan dan dibuat skala prioritasnya. Mereka mengurutkan masalah yang perlu dicarikan solusinya terlebih dahulu. Untuk mengatasi masalah pengangguran dan kemiskinan, warga mengusulkan diadakannya kursus sesuai dengan keterampilan yang dibutuhkan. Seperti yang disampaikan oleh Am (Nov 2005), salah seorang warga RW 03 bahwa ia hadir setiap arisan bulanan RT. Hal ini membuat ia menjadi tahu permasalahan yang ada di RT. Pada pertemuan tersebut ia juga memberikan usulan keterampilan yang diinginkannya.

Hal ini juga diungkapkan sebelumnya oleh beberapa TPK/UPK RW dan Dekel RW. Seperti yang dikatakan oleh TPK RW 03, Sla (Agus 2005) bahwa ia menampung masalah masyarakat. Ia juga menampung usulan masyarakat untuk bina sosial yang akan dilaksanakan nantinya. Namun, tidak semua masyarakat yang memberikan usulan, tetapi hanya sebagian saja.

Sama halnya pada tahap assessment, tahap perencanaan juga dilakukan di tingkat kelurahan (pertemuan forum warga) pada tahun 2002. Identifikasi masalah dan usulan pemecahan masalah yang sudah dibahas di tingkat RT dan RW kembali 
dibicarakan. Berdasarkan masukan tersebut, di pertemuan forum warga itu juga dilakukan skala prioritas untuk seluruh permasalahan yang ada dan mengatasinya. Bedanya dengan pertemuan tingkat RT dan RW adalah pada tingkat kelurahan, permasalahan dan pemecahan untuk skala lebih besar, yaitu tingkat Kelurahan Klender. Permasalahan yang sudah diidentifikasi dan diurutkan diberikan penomoran untuk diselesaikan terlebih dahulu.

Sebelum dilaksanakan perencanaan bina sosial, Dekel membuat angket atau daftar isian yang disebarkan ke masyarakat melalui TPK RW dan RT. Angket atau daftar isian tersebut berisi daftar pelatihan atau kursus yang dapat dipilih masyarakat. Angket itu berisi himbauan agar masyarakat menyampaikan keinginannya kepada RT/RW/ Dekel. Keinginan tersebut adalah di bidang sosial untuk meningkatkan keterampilannya. Jadi, masyarakat diminta membuat usulan kursus yang diinginkan sesuai dengan kebutuhannya.

Meskipun sudah ada forum untuk penyampaian aspirasi masyarakat, masih ada anggota masyarakat yang langsung menyampaikan usulan kepada TPK/UPK RW dan Dekel. Hal ini diungkapkan oleh End, anggota Dekel RW 01 dan Nur, RW 13. Menurut mereka, ada beberapa masyarakat RW-nya yang memberikan usulan kursus kepada mereka sesuai dengan kebutuhan mereka.

\section{Kita telah mensosialisasikan program bina sosial melalui angket. Angket tersebut disebarkan oleh pihak RT masing-masing di wilayahnya. Diharapkan masyarakat memberikan usulan, apakah langsung ke Dewan Kelurahan atau melalui RT atau TPK RW.(Sub, Agus 2005)}

Daftar isian ini disebarkan oleh Dekel ke masyarakat melalui TPK RW dan RT setiap dana akan dicairkan, yaitu pada awal tahun 2002, tahun 2004 dan 2005. Pada tahun 2003, Dekel tidak menyebarklan angket karena tidak ada anggaran pada tahun tersebut.

Proses final, yakni jenis kursus yang akan dilaksanakan ditentukan dari jumlah usulan yang dimasukan oleh masyarakat. Dekel hanya mengolah data usulan yang masuk. Jadi, masyarakat sendirilah yang menentukan kursus yang akan dilaksanakan.
Menurut Ketua Dekel, hasil penghitungan usulan kursus ini disosialisasikan lagi ke masyarakat. Sosialisasi ini pun berjenjang dari Dekel ke RW/ TPK RW. RW/TPK RW melanjutkan ke RT dan RT menyampaikan ke masyarakat. Selain itu, Dekel juga membuat spanduk yang dipasang di beberapa daerah atau pusat keramaian.

Jadi, proses perencanaan bina sosial di Kelurahan Klender berdasarkan kepada aspirasi masyarakat yang masuk ke Dekel Klender. Partisipasi masyarakat memberikan usulan sangat menentukan program yang akan dilaksanakan. Namun, masyarakat tidak tahu usulan yang paling banyak itu apa, karena mereka tidak dihadirkan dalam pertemuan Dekel. Masyarakat diberitahu hasil terbanyak usulan tersebut setelah dilakukan pembahasan di Dekel. Proses penentuan kursus ini menurut ketua Dekel Klender, Sub, (April 2006) masyarakat memilih tiga kursus yang di-inginkannya dari sepuluh jenis kursus yang telah dimuat dalam daftar isian. Mereka juga mengisi nama lengkap, umur dan alamatnya. Hal ini bertujuan agar Dekel bisa meng-hubungi mereka kembali melalui TPK RW masing-masing. Jenis usulan yang sedikit, maka Dekel memanggil mereka yang mengusulkan dan menjelaskan bahwa usulan mereka tidak bisa dilaksanakan. Mereka dipersilahkan memilih kursus yang lebih banyak diusulkan.

Meskipun sudah ada pertemuan forum warga dan ada penyebaran angket, tidak semua masyarakat berpartisipasi dengan memberikan usulan. Dari beberapa masyarakat yang diwawancarai, ada di antara mereka mengatakan tidak tahu kalau mereka harus memberikan usulan rencana kegiatan bina sosial. Seperti ungkapan salah seorang warga, Wan (Agus 2005) mengatakan bahwa ia tidak tahu ada usulan kursus di kelurahan. RT tidak memberitahukannya. Ia hanya tahu ada pinjaman bergulir di RW. Sementara itu, pihak LSM melihat bahwa perencanaan bina sosial ini sudah aspiratif. Masyarakat mengusulkan jenis kursus melalui RT atau bisa langsung ke Dekel RW. Begitu juga dengan proses sosialisasinya dianggap sudah baik, yakni secara berjenjang (struktural), yakni Dekel mensosialisasikan ke RW/TPK RW, selanjutnya RW/TPK RW meneruskan sosialisasi ke RT masingmasing. Terakhir, RT mensosialisasikan lebih gencar ke warganya. Jadi, menurut Direktur LSM LPPSE, kalau informasi tersebut tidak sampai ke masyarakat, 
itu adalah kesalahan RT. Diakuinya memang ada RT yang tidak mensosialisasikannya ke Warga. Pihak RT menyimpan selembaran tersebut.

\section{Gambaran Partisipasi Masyarakat pada Tahap Pelaksanaan}

Pelaksanaan bina sosial pertama kalinya dilaksanakan pada tahun 2002. Masyarakat ada yang berpartisipasi sebagai peserta kursus dan sebagai instruktur kursus. Agar bisa menjadi peserta kursus, mereka mendaftarkan diri terlebih dahulu. Pendaftaran ini bisa dilakukan langsung ke kelurahan maupun ke Dekel RW-nya. Sementara itu, pihak RT, RW, TPK/UPK RW dan Dekel membantu masyarakat mendaftar sebagai peserta kursus. Pada saat pendaftaran, mereka menentukan sendiri kursus yang diinginkan sesuai dengan apa yang telah ditentukan. Kalau mereka memilih komputer atau yang lainnya, mereka pun bebas menentukan waktunya. Mereka bisa menyesuaikan dengan waktu kosongnya atau yang tepat, baik hari maupun pukulnya. Masyarakat mengikuti pelatihan atau kursus dengan baik dan hampir tidak ada yang libur atau absen. Seperti ungkapan seorang warga yang mendaftarkan anaknya untuk menjadi peserta kursus.

\section{Saya memang tidak tahu ada perencanaan kursus, tapi ketika tahu ada pelaksanaannya, saya pun mendaftarkan anak saya melalui Dekel RW saya untuk ikut kursus komputer. Anak saya mengikuti kursus sampai selesai. (Wan, Agus 2005).}

Masyarakat berpartisipasi sebagai peserta kursus karena mereka memang membutuhkan keterampilan untuk mencari pekerjaan. Selain itu, jenis kursus yang dilaksanakan di Dekel menurut mereka mempunyai peluang kerja yang banyak. Seperti kursus menyetir, mereka bisa bekerja sebagai sopir angkutan kota, sopir perusahaan atau sopir pribadi. Bahkan, mereka berpartisipasi sebagai peserta kursus karena tidak dipungut biaya. Mereka mengakui tidak punya uang untuk ikut kursus. Khusus kursus mengemudi, setelah kursus mereka dibantu oleh Dekel mengurus SIM, sehingga memudahkan mereka mencari pekerjaan. Mereka yang telah mengikuti kursus menjahit atau komputer, ingin membuka usaha sendiri, seperti menerima upah jahitan atau membuka rental komputer, maka mereka dibolehkan mengusulkan pinjaman modal. Kalau memang mereka layak, mereka akan diberikan pinjaman. Menurut Ketua Dekel, Sub (April 2005) ada beberapa peserta kursus komputer dan menjahit yang mendapatkan bantuan modal dari bina ekonomi.

Masyarakat tidak hanya berpartisipasi sebagai peserta, tetapi juga ada berpartisipasi sebagai instruktur kursus. Ada di antara mereka mejadi instruktur menjahit, servis telepon genggam, bahasa Inggris, hias hantaran penganten, mengemudi, dan komputer. Mereka mau diberi honor kecil. Meskipun honornya kecil, mereka tidak pernah bolos. Hal ini sesuai dengan apa yang dikatakan ketua Dekel bahwa instruktur kursus diambil dari warga yang punya keahlian di bidang tersebut. Sebagai imbalan mereka diberi honor. Meskipun honornya tidak besar, mereka bersedia ketika dihubungi. Jadi, masyarakat banyak berpatisipasi sebagai peserta kursus, seperti: komputer,menjahit, dan mengemudi. Mereka tidak ada yang mengundurkan diri ketika kursus berjalan. Bahkan, ketika kursus hampir selesai, ada di antara mereka ditawarkan pekerjaan, seperti sopir pribadi. Selama tahun 2002-2005 Dewan Kelurahan telah melaksanakan sepuluh jenis kursus. Tahun 2002, kursus yang dilaksanakan ada tiga jenis, yaitu: komputer, mengemudi, dan tata busana. Tahun 2004, kursus yang dilaksanakan ada empat jenis, yaitu: melanjutkan tiga jenis kursus pada tahun 2002 dan ditambah kursus boga serta MC. Sedangkan pada tahun 2005, Dekel melaksanakan sepuluh jenis kursus, yaitu melanjutkan empat jenis kursus pada tahun 2004 dan ditambah enam jenis kursus lagi. Keenam jenis kursus tersebut adalah kursus memperbaiki telepon genggam, otomotif, bahasa Inggris, hias hantaran penganten, pemberdayaan TPK/UPK RW dan penguatan kelembagaan.

Pelaksanaan bina sosial ini ditunjang dengan membeli sepuluh unit komputer, dua unit mobil, dan enam buah mesin jahit pada tahun 2002. Dengan adanya fasilitas tersebut, pada tahun 2004 Dewan Kelurahan Klender telah berhasil melaksanakan dua paket kursus menjahit, enam paket kursus mengemudi dan lima paket kursus komputer.

Kegiatan kursus komputer yang dilaksanakan selama dua bulan, tiga kali seminggu, dengan jumlah satu kelompok 8-10 orang. Kelompok tersebut ada 
empat. Dalam satu hari langsung empat kelompok dengan jadwal, yakni mulai pukul 08.00-10.00, pukul 10.00-12.00, pukul 12.00-14.00 dan pukul 14.00-16.00 Sedangkan kursus menjahit dilaksanakan selama enam bulan. Jumlah orang dalam satu kelompok delapan orang dan jumlah pertemuan tiga kali seminggu. Sementara kursus menyetir mobil hanya satu bulan. Satu mobil untuk enam orang. Kursus ini juga dilaksanakan tiga kali seminggu. Ketiga kursus tersebut dilaksanakan oleh Dekel bekerja sama dengan warga Kelurahan Klender sebagai instrukturnya. Berdasarkan dari Laporan Hasil Monitoring PPMK Tahun 2001-2004, jumlah pemanfaat kursus menyetir 360 orang, menjahit 200 orang dan komputer 260 orang. Sementara itu, pelatihan tata boga dan MC yang dilaksanakan Dekel bekerja sama dengan PKK kelurahan berhasil melatih 112 orang pada tahun 2004. Selain empat kursus atau pelatihan di atas, Dekel juga berhasil melaksanakan pelatihan penanganan kredit bermasalah di Cisarua Bogor. Pelatihan ini dilaksanakan kerja sama dengan LSM pen-damping (LPPSE).

Kursus menjahit dan mengemudi, pada umumnya diikuti oleh warga yang menganggur dan ingin mencari pekerjaan. Seperti kursus mengemudi, pesertanya pada umumnya mereka yang ingin menjadi sopir. Ada di antara mereka yang sudah pernah menyetir mobil, namun lebih banyak yang tidak pernah menyetir mobil. Menurut instruktur kursus menyetir An (Nov 2005), peserta kursus serius dalam latihan. Mereka tidak pernah bolos, kalaupun ada yang bolos disebabkan mereka sibuk memasukkan lamaran pekerjaan. Menurutnya, kursus menyetir ternyata membutuhkan keberanian. Sehubungan dengan hal tersebut, ia membawa peserta kursus mengemudi di kawasan industri Polo Gadung. Setelah mengikuti kursus menyetir satu bulan, Dekel membantu mengurus SIM peserta kursus. Berdasarkan informasi yang telah diperoleh dari TPK RW, Dekel RW dan instruktur kursus mengemudi, masyarakat yang telah mengikuti kursus mengemudi selama satu bulan sudah banyak yang mendapatkan pekerjaan. Mereka banyak menjadi sopir pribadi dan sopir angkot. Namun, Dekel tidak mendata jumlah mereka yang sudah bekerja dan yang belum.

Di sisi lain, untuk kursus menjahit, meskipun peserta hanya diberi keterampilan dasar menjahit selama enam bulan, mereka sudah mahir menjahit.
Menurut Sub, ketua Dekel, mereka banyak yang diterima bekerja di konveksi di Pulo Gadung. Mereka yang tidak bekerja di luar rumah, memutuskan untuk membuka usaha sendiri di rumah. Semntara itu, peserta kursus komputer pada umumnya adalah lulusan SLTA. Meskipun kursus untuk mereka yang tidak melanjutkan ke perguruan tinggi atau akademi dan membutuhkan keterampilan untuk mencari kerja, Dekel tidak melarang mereka yang masih duduk di bangku sekolah. Pelajar yang boleh menjadi peserta kursus komputer minimal duduk di bangku kelas II SLTA. Hasil yang diharapkan dari kursus komputer ini adalah memudahkan mereka mendapatkan pekerjaan. Sama halnya dengan kursus menjahit, lulusan kursus komputer juga mendapatkan sertifikat yang dikeluarkan oleh Dekel Klender.

\section{Gambaran Partisipasi Masyarakat pada Tahap Evaluasi}

PPMK sudah dicanangkan sejak tahun 2001 di Jakarta termasuk Kelurahan Klender. Kelurahan Klender mulai melaksanakan program tersebut pada tahun 2002 untuk bina sosial dan fisik setelah dana cair pada akhir tahun 2001. Berdasarkan temuan lapangan, evaluasi langsung dilakukan oleh Badan Pemberdayaan Masyarakat (BPM) Kota Jakarta Timur dan LSM pendamping. Sementara itu, pihak Kelurahan dan Dekel Klender hanya melaksanakan monitoring pelaksanaan PPMK di kelurahan tersebut. Pihak Dekel memberikan laporan pelaksanaan bina sosial ke BPM Kota Jakarta Timur. Laporan ini langsung dibuat Dekel. Hal ini berbeda dengan laporan untuk bina fisik dan ekonomi. Laporan bina fisik dan ekonomi dibuat Dekel berdasarkan laporan dari TPK RW. Masyarakat, RT, RW dan TPK/UPK mengkui bahwa mereka tidak terlibat dalam evaluasi kegiatan bina sosial. Mereka tidak tahu baik atau buruknya pelaksanaan bina sosial di Kelurahan Klender. Apalagi, pelaksanaan bina sosial dipusatkan di kelurahan.

\section{Bina Fisik} Gambaran Partisipasi Masyarakat pada Tahap
Assessment Assessmentkegiatan bina fisik dilaksanakan 
bersamaan dengan bina sosial. Untuk tingkat RT, assessment dilaksanakan pada tahun 2002, yaitu setelah dana PPMK untuk bina ekonomi dicairkan pada November 2001. Assessmentbina fisik kembali dilaksanakan pada tahun 2004 dan tahun 2005, karena pada tahun tersebut dana kembali dikucurkan. Pada bina fisik ini, identifikasi masalah sama dengan pada bina sosial. Masyarakat mengidentifikasi masalah (assessment) secara bertahap juga. Tahap tersebut dimulai dari tingkat RT, RW sampai tingkat kelurahan, yaitu pada pertemuan forum warga. Pada tingkat RT, masyarakat langsung mengidentifikasi masalah fisik lingkungan yang mereka rasakan dan lihat. Untuk bidang fisik ini, masyarakat lebih mudah melakukan assessment. Alasan mereka karena bisa dilihat dan dirasakan secara langsung.

Assessment bina fisik pada tahun 2004 dan 2005 hanya sampai pada tingkat RT dan RW. Untuk tingkat kelurahan tidak ada pada tahun tersebut. Menurut Ketua Dekel, Sub (April 2006) assessment tingkat kelurahan tidak ada karena di Kelurahan Klender tidak dilaksanakan pertemuan forum warga. Menurutnya, seharusnya pertemuan forum warga dilaksanakan setiap tahun karena hasil pertemuan forum warga merupakan dasar dari Kelurahan dalam membuat perencanaan pembangunan untuk tahun yang akan datang.

Bagaimana assessment untuk bina fisik, dapat dilihat dari apa yang diungkapkan oleh salah seorang warga, Am (Nov 2005). Menurutnya, mereka tidak hanya membicarakan masalah sosial, tapi juga fisik dan lingkungan, seperti saluran yang tersumbat dan jalan yang tidak bagus pada pertemuan arisan bulanan. Malah lanjutnya, sebelum ada PPMK, mereka telah memperbaiki saluran air dengan sistem swadaya.

Sebelumnya, beberapa pengurus RT, seperti Dal (RT 05/RW 01) dan Nas (RT 01/RW 15) juga mengungkapkan hal yang sama. Mereka ada yang mengeluhkan kondisi jalan yang masih tanah dan sering becek kalau hujan. Selain itu, saluran pembuangan air yang sering tersumbat dan masih sempit, sehingga pada musim hujan sering banjir. Selanjutnya, masyarakat yang memanfaatkan fasilitas tempat mandi, cuci dan kakus (MCK) umum selama ini mengeluhkan masih kurangnya MCK umum. Mereka harus antri karena MCK umum masih kurang.

Berdasarkan informasi yang diberikan oleh
Ketua Dekel Sub dan laporan pertemuan forum warga, hasil identifikasi bidang fisik lingkungan pada tahun 2002 antara lain: masih banyaknya jalan setapak, MCK umum yang kurang memadai, saluran air di beberapa wilayah yang sering tersumbat, sarana keamanan dan sarana kebersihan yang masih minim. Jadi, pada tahap ini, masyarakat ikut terlibat dalam merumuskan masalah yang ada dilingkungannya. Keterlibatan masyarakat secara langsung pada pertemuan tingkat RT. Sedangkan keterlibatan tidak langsung pada pertemuan tingkat RW dan Kelurahan.

\section{Gambaran Partisipasi Masyarakat pada Tahap Perencanaan}

Identifikasi masalah yang dilakukan mulai ditingkat RT sampai pada forum kelurahan dilanjutkan pada tahap perencanaan pada tahun 2002. Sama halnya dengan bina sosial, pada bina fisik ini, masalah yang sudah diidentifikasi berdasarkan kebutuhan masyarakat di tingkat RT dan RW tersebut dibahas dalam forum warga dan dibuatkan skala prioritasnya. Pada perencanaan bina fisik, skala prioritas juga ditentukan masyarakat (perwakilan masyarakat RT) sendiri bersama dengan tokoh masyarakat, RT, RW, Dekel RW dan TPK RW-nya. Hal ini juga dilakukan pada tahun 2004 dan tahun 2005. Namun, pada tahun 2004 dan tahun 2005, perencanaan bina fisik hanya pada tingkat RT dan RW. Perencanaan bina fisik tidak ada di tingkat kelurahan, karena di kelurahan tidak dilaksanakan pertemuan forum warga pada tahun 2004 dan 2005.

Warga bersama RT-nya membuat proposal usulan kegiatan yang akan dilaksanakan. Proposal ini sesuai dengan hasil perumusan masalah lingkungan yang ada dan telah dibahas (pada tahap assessment) di setiap pertemuan bulanan warga. Di sini peranan pengurus RT hanya memfasilitasi warganya untuk membuat atau merumuskan proposal pembangunan di wilayahnya. Hal ini sesuai dengan apa yang diungkapkan salah seorang warga Am. Menurutnya, warga merancang proposal bersama pengurus RT di rumah ketua RT. Meskipun jumlah warga yang datang tidak terlalu banyak jika dibandingkan pada arisan bulanan, hal itu sudah mewakili. Proposal yang dibuat, lanjutnya, tidak terlepas dari hal yang telah dibahas pada arisan bulanan.

Sebelumnya, hal ini diungkapkan oleh Ketua 
Dekel, seperti kutipan di bawah ini.

Perencanaan di bina fisik diserahkan
oleh dewan kelurahan ke masing-masing
$R T$. RT membuat proposal perencanaan
bersama warganya dan diusulkan ke TPK
$R W$. TPK RW memfasilitasi pertemuan
untuk memusyawarahkan penentuan bina
fisik yang akan dilaksanakan. Setelah itu,
setiap TPK RW mengusulkan ke Dewan
Kelurahan program bina fisik yang akan
dilaksanakan di RW-nya. (Sub, Agus 2005)

Masyarakat mempunyai wewenang untuk menentukan program yang akan dilaksanakan tersebut. Wewenang tersebut terlihat dari prosedur penetapan lokasi pembangunan fisik, yakni pada musyawarah warga RW. Pada musyawarah tersebut, TPK RW menjelaskan dan memperlihatkan ke masyarakat proposal yang masuk. Selain itu, TPK juga telah melakukan survei ke setiap RT berdasarkan proposal yang masuk dari RT. Hasil survei ini disampaikan pada saat musyawarah warga RW. Setelah itu, semua proposal dibahas bersamasama, ditentukan bina fisik yang akan dilakukan berdasarkan skala prioritas.

Tim TPK RW melaksanakan seleksi program bina fisik dari setiap proposal yang diajukan oleh masing-masing RT-nya. Hasil ini dibahas dan dimusyawarahkan pada pertemuan warga di RW, agar setiap warga RT bisa memahami permasalahan yang paling prioritas.

Namun, ada RT yang membuat proposal perencanaan tanpa melibatkan masyarakatnya. Jadi, ada masyarakat yang tidak berpartisipasi dalam perencanaan untuk menentukan skala prioritas pembangunan fisik di ligkungannya. Hal ini dapat dilihat dari apa yang diungkapkan Dal, Ketua RT 5 RW 01 (Agus 2005) bahwa perencanaan bina fisik dilakukan dengan membuat proposal hanya bersama pengurus RT. Hal ini dilakukannya karena ia dan pengurus RT lainnya sudah tahu apa yang dibutuhkan masyarakat karena melihat sendiri kondisi fisik di lingkungannya dan keluhan masyarakat selama ini.

Jadi, ada proposal dibuat pengurus RT dengan beberapa tokoh masyarakat di RT tanpa melibatkan masyarakat dan langsung mengusulkannya ke TPK RW. Bahkan, ada RT yang sama sekali tidak melibatkan masyarakat maupun tokoh masyarakat.
Ketua RT membuat proposal hanya berdua dengan sekretarisya. Seperti yang dikatakan oleh Ketua RT 01 RW 15 di bawah ini.

\begin{abstract}
Kami tidak melibatkan masyarakat dalam perencanaan bina fisik. Saya hanya berdua dengan sekretaris RT membuat proposal perencanaan bina fisik. Hal ini disebabkan waktu untuk mengadakan rapat dengan warga dan pengurusnya tidak ada. Waktu terlalu mepet. Selain itu, saya dan sekretaris saya beranggapan bahwa usulan masyarakat tidak jauh berbeda dengan kenyataan atau permasalahan yang ada di RT. (Nas, Sep 2005)
\end{abstract}

Informasi yang diperoleh di lapangan adalah ada informan tidak mengetahui adanya perencanaan bina fisik. Mereka tiba-tiba diberi tahu untuk ikut gotong royong melaksanakan pembangunan bina fisik. Bahkan, ada di antara mereka yang tahu ada bina fisik pada saat pekerjaan itu berlangsung di dekat rumahnya. Hal ini dapat dilihat dari apa yang diungkapkan oleh salah seorang warga, Ded, warga RT 01 RW15 (Sep 2005). Menurutnya, ia tidak tahu sama sekali ada rapat untuk merencanakan bina fisik. Jangankan itu, PPMK ia juga tidak tahu. Apakah ia yang tidak aktif karena terlalu disibukan dengan usaha dagang kulit kambing ini atau memang pihak RT yang tidak memberitahukannya.

\section{Gambaran Partisipasi Masyarakat pada Tahap Pelaksanaan}

Bina fisik di Kelurahan Klender dilaksanakan setelah tahap perencanaan di masing-masing RW terlaksana. RW melalui musyawarah memutuskan bina fisik yang akan dilaksanakan. Setelah itu, proposal tersebut diajukan oleh TPK RW ke Dekel. Dekel mencairkan dana bantuan bina fisik ini secara bertahap, yaitu sebanyak tiga tahap. Dana tahap awal ini dicairkan setelah proposal yang diajukan TPK RW disurvei dan disetujui. Dana tahap dua dicairkan setelah laporan tahap awal diberikan oleh TPK ke Dekel. Terakhir, dana tahap ketiga dicairkan setelah TPK memberikan laporan akhir pelaksanaan bina fisik.

Ketika masyarakat diberi tahu oleh RT-nya bahwa di daerah mereka akan diadakan pembangunan 
(seperti saluran air, jalan setapak, MCK, dan balai warga) mereka memberikan tanggapan yang positif. Mereka ikut meninjau lokasi yang akan dibangun. Mereka menghadiri pertemuan yang diadakan oleh pihakRT dan RW untukmenentukan kapan pelaksanaan yang tepat. Bentuk keterlibatan masyarakat dalam pelaksanaan bina fisik ini bermacam-macam. Ada di antara mereka yang berpartisipasi dalam bentuk tenaga. Hal ini sesuai dengan daerah (RT) yang menjadi pemanfaat bina fisik. Seperti pembangunan saluran air, apabila kelompok pemanfaatnya ada di empat RT, setiap anggota RT bergantian bergotong-royong. Alasannya, mereka juga mempunyai kesibukan untuk mencari nafkah.

Bentuk partisipasi masyarakat yang lain itu adalah menyumbangkan makanan kecil pada saat kerja bakti tersebut, meminjamkan alat-alat yang dibutuhkan dalam pembangunan sarana seperti alat pertukangan, dan ada yang berpartisipasi meminjamkan tanahnya untuk dipakai membangun sarana (seperti untuk pembangunan MCK dan balai warga). Hal ini dapat dilihat dari apa yang diungkapkan oleh salah seorang warga, Ras (Agus 2005). Warga RT 13 RW 03 ini mengatakan bahwa ia hanya bisa menyumbangkan makan kecil untuk Bapak-Bapak yang sedang bekerja bakti. Selain itu, juga dikatakan bahwa ia tidak punya uang untuk disumbangkan. Sementara itu, Sot (Agus 2005) yang juga warga RT 13 RW 03 mengatakan bahwa ia membantu teman-teman yang gotong-royong membangun jalan. Ia membantu kalau sudah pulang dari berdagang. Selain itu, juga dikatakan bahwa ia hanyalah orang miskin sehingga tidak punya uang untuk di sumbangkan. Ia hanya punya tenaga untuk disumbangkan.

Bahkan, ada di antara mereka yang seharihari bekerja sebagai kuli bangunan, mau bekerja sebagai tenaga upahan pada pelaksanaan program dengan honor yang tidak terlalu besar. Meskipun bentuk partisipasi dalam bentuk uang tidak banyak, masih ada masyarakat yang menyumbang uang. Seperti yang diungkapkan salah seorang anggota Dekel, Nur, "Pembangunan balai warga di RW saya yang anggarannya sedikit dibantu penyelesaiannya oleh salah seorang warga yang memang bekerja sebagai pengusaha." (Agus, 2005)

Mereka berpartisipasi dalam pelaksanaan bina fisik karena mereka memang membutuhkan pembangunan sarana tersebut. Pembangunan saluran air akan membuat rumah mereka tidak terkena banjir lagi waktu musim hujan. Begitu juga dengan pembangunan MCK dan jalan setapak, mereka bisa memanfaatkannya. Alasan lainnya, mereka memang peduli dengan kondisi lingkungan. Apalagi selama ini mereka selalu bergotong-royong untuk membersihkan lingkungannya. Mereka mengaku malu kalau tidak ikut bergotong-royong.

Meskipun demikian, pada tahun 2005 ini, di RW 03 masyarakat tidak terlibat dalam pelaksanaan bina fisik. Hal ini tidak hanya dialami oleh warga, tetapi juga oleh pengurus RT. Tej, Ketua RT 14 RW 03 dan Hil, Ketua RT 08 RW 03 mengakui bahwa mereka tidak tahu ada pembangunan sarana fisik. Menurut Tej, pelaksanaan bina fisik di RT 14 RW 03 yang barubaru ini ada adalah pengaspalan jalan di ganggang yang melalui RT 14. Pengaspalan ini tidak melibatkan warga, karena dilakukan pada malam hari dan telah ditentukan oleh RW dan TPK RW pemborongnya. Hal senada juga diungkapkan Hil, Ketua RT 08 RW 03, bahwa masyarakat tidak terlibat dalam pelaksanaan, khususnya bina fisik yang dilaksanakan di RT-nya.

Saya tidak tahu kapan jalan di RT saya
diaspal. Apakah mereka mengerjakannya di
malam hari? Pada sore sebelumnya kondisi
jalan belum beraspal. Saya juga tidak tahu
sumber dana pengaspalan jalan gang RT 7
dan 8. (Feb, 2006).

Sedangkan anggaran untuk bina fisik ini sudah ditentukan oleh Dekel untuk setiap RW. Dana ini dicairkan oleh Dewan Kelurahan Klender ke masing-masing RW pada tahun 2002. Jumlah dana pelaksanaan bina fisik tahun 2002 yang diserahkan ke setiap RW berbeda-beda. Dana paling banyak diberikan ke RW 04 yakni Rp 37,5 juta. Dana ini digunakan untuk perbaikan saluran air dan jalan setapak. Sedangkan dana paling sedikit dicairkan di RW 14, yakni Rp 20 juta. RW 14 menggunakan dana tersebut untuk perbaikan saluran dan pembangunan MCK. Jumlah dana keseluruhan yang telah dicairkan untuk pelaksanaan bina fisik tahun 2002 adalah $\mathrm{Rp}$ 491.273.000,00. Dana ini telah dimafaatkan oleh $5.094 \mathrm{KK}$

Adapun kegiatan bina fisik tahun 2002 tersebut adalah: membuat saluran air, pembangunan MCK, pembangunan jalan setapak, pembuatan bak sampah, dan pembangunan balai pertemuan warga. 
Namun, kegiatan yang paling banyak dilakukan adalah perbaikan saluran air dan perbaikan jalan setapak. Sementara itu, tahun 2004 jumlah dana yang diberikan pada setiap RW sama. Dana diberikan kepada setiap RW berjumlah Rp 7 juta pada tahun 2004. Jadi, jumlah dana yang dialokasikan untuk bina fisik tahun 2004 Rp 126 juta. Jumlah pemanfaat bina fisik ini di masing-masing RW berbeda-beda. Jumlah pemanfaat paling banyak RW $03 \quad 1.125$ KK. Sebaliknya, pemanfaat paling sedikit RW 05, 14 dan RW 18, masing-masing 75 KK. Jumlah KK pemanfaat untuk bina fisik tahun 2004 adalah 5.250 KK. Bentuk kegiatan bina fisik tahun 2002 hampir sama dengan tahun 2004.

\section{Gambaran Partisipasi Masyarakat pada Tahap Evaluasi}

Sama halnya dengan bina sosial, masyarakat juga tidak dilibatkan dalam evaluasi bina fisik. Masyarakat hanya tahu pelaksanaan bina fisik di wilayahnya saja. Masyarakat hanya bisa memberikan penilaian pelaksanaan bina fisik di wilayahnya juga karena mereka terlibat dalam pelaksanaannya. Masyarakat tidak tahu pelaksanaan bina fisik di Kelurahan Klender secara keseluruhan. Menurut Sla, TPK/UPK RW 03, untuk bina fisik ia hanya memberikan laporan kegiatan. Laporan ini diberikan sebanyak tiga kali, yakni laporan tahap awal, tahap per-tengahan dan tahap akhir ke Dekel. Apakah pelaksanaan di derahnya lebih baik dari RW lainnya atau tidak, ia tidak mengetahuinya.

\section{Bina Ekonomi}

Bina ekonomi dilaksanakan di Kelurahan Klender pada tahun 2001. Bina ini lebih dahulu dilaksanakan dibandingkan kedua bina yang lainnya. Menurut Ketua Dekel, Sub (April 20065), alasan bina ekonomi lebih awal, karena prosedurnya lebih cepat. Pihaknya tidak perlu membuat perencanaan terlebih dahulu. Pihaknya langsung meminta TPK RW untuk menyeleksi dan membuat daftar nama pemanfaat bina ekonomi.

\section{Gambaran Partisipasi Masyarakat pada Tahap Assessment}

Pada tahun 2001, ketika dana untuk bina ekonomi akan dicairkan, Dekel Klender langsung meminta masyarakat mengisi daftar isian untuk mengusulkan pinjaman. Permintaan ini melalui TPK RW. Jadi, pada tahun 2001 tidak ada assessment di bidang ekonomi. Alasan Dekel, karena waktunya yang terlalu pendek. Dekel berusaha agar dana untuk bina ekonomi bisa dicairkan dan tidak harus menunggu tahun anggaran 2002.

Identifikasi atau pemetaan masalah oleh masyarakat untuk PPMK di bidang ekonomi baru dilaksanakan pada tahun 2002. Identifikasi masalah yang dihadapi masyarakat dilakukan pada tingkat RT, RW dan kelurahan pada tahun 2002. Sedangkan pada tahun 2004 dan 2005 identifikasi masalah hanya di tingkat RT dan RW. Identifikasi pada bidang ekonomi ini sangat berkaitan dengan bidang sosial. Ala-sannya, masalah pengangguran dan kemiskinan yang dialami sekelompok warga memengaruhi perekonomian mereka. Mereka tidak memiliki keterampilan sehingga sulit mencari pekerjaan. Hal ini membuat keluarganya tidak memiliki sumber keuangan. Kalaupun ada di antara mereka yang berusaha dengan membuka usaha dagang, mereka masih mengalami kekurangan modal. Ada juga di antara mereka sudah memiliki keterampilan tapi belum juga mendapat pekerjaan. Selain itu, ada di antara mereka dipihak dari pekerjaannya. Jadi, pada umumnya mereka mempersoalkan cara meningkatkan pendapatan keluarganya.

\section{Gambaran Partisipasi Masyarakat pada Tahap Perencanaan}

Meskipun pada tahap assessment telah diidentifikasi kebutuhan bina ekonomi masyarakat oleh masyarakat sendiri, dalam tahap perencanaan masyarakat tidak berperan serta. Perencanaan bina ekonomi ini tidak ada sejak tahun 2001-2005, karena pihak Dekel sudah menyediakan hal-hal yang diperlukan oleh masyarakat pada pelaksanaan bina ekonomi. Hal yang telah disediakan itu seperti formulir yang harus diisi oleh masyarakat nantinya (dikenal dengan sebutan proposal), peraturan dan jumlah dana yang digulirkan.

Pihak pelaksana program bina ekonomi memberikan keterangan melalui sosialisasi PPMK. Ketika tahu ada sosialisasi PPMK, mereka ikut dan menjadi pendengar yang baik. Mereka mendengarkan uraian, khususnya tentang pinjaman 
bergulir, terutama sekali persyaratan dan prosedur peminjaman. Selain itu, hal-hal yang harus mereka persiapkan terlebih dahulu.

Meskipun mereka sudah menjadi pendengar yang baik, karena tingkat pendidikan yang rendah dan usia yang sudah tua, mereka mengalami kesulitan untuk memahami prosedur dan persyaratan pinjaman bergulir ini. Namun, mereka tidak berputus asa. Setelah sosialisasi selesai, mereka mendatangi pengurus RW, TPK RW atau Dekel RW. Di sana mereka menanyakan hal yang tidak mereka pahami.

\section{Gambaran Partisipasi Masyarakat pada Tahap Pelaksanaan}

Menurut warga, TPK/UPK dan Dekel, setelah mengikuti sosialisasi PPMK dan mengerti prosedur peminjaman dana bergulir pada tahun 2001, masyarakat pun membentuk kelompok pemanfaat (Komat). Setelah Komat dibentuk, mereka memilih ketuanya dan memberi nama Komatnya. Di kelompok tersebutlah, anggota mendiskusikan jumlah pinjaman kelompoknya dan jumlah dana yang diperoleh masing-masing anggota.

Setelah ada kesepakatan di Komat, mereka mengisi sendiri formulir pinjaman. Mereka yang tidak mengerti cara mengisi formulir tersebut, atau ada yang diragukan, biasanya mereka menayakan terlebih dahulu dalam Komatnya. Tapi kalau anggota Komat yang lain tidak bisa menjelaskan, mereka mendatangi TPK RW/Dekel bahkan LSM untuk minta penjelasan. Seperti yang diungkapkan Ast (Agus 2005), bahwa ia langsung menemui Dekel RW-nya setelah sosialisasi dana bergulir. Ia menanyakan persyaratan lebih rinci dan Dekel RWnya pun menjelaskannya.

Begitu juga anggota masyarakat yang buta huruf, mereka ada yang minta bantuan kepada anggota keluarganya atau kepada TPK/UPK/Dekel RW. Mereka membacakan isi formulir tersebut sehingga anggota masyarakat yang buta huruf tersebut tahu apa maksudnya. Anggota masyarakat tersebut pun mendiktekan apa yang ingin ia tuliskan dan pihak keluarga atau TPK/UPK/Dekel RW yang menuliskannya. nJadi, masyarakat mengisi formulir isian yang sudah disediakan. Terserah mereka mengusulkan peminjaman berapa, tergantung kesepakatan dalam Komatnya. Setelah semua anggota dalam satu Komat selesai mengisi formulir, ketua
Komat mengantarkan semua formulir anggotanya ke TPK RW.

Menurut Dekel RW dan TPK/UPK RW masyarakat betul-betul antusias. Seperti yang diungkapkan oleh UPK RW 15 Pur (Sep 2005), setelah ada sosialisasi program, warga tidak hentihentinya mendatangi rumahnya untuk menanyakan cara agar mereka bisa meminjam uang. Bahkan, ia membantu mereka megisi formulir tersebut. Jadi, jumlah alokasi bina ekonomi un-tuk masing-masing daerah tidak ditentukan oleh pihak Dekel, tetapi ditentukan oleh masyarakat sendiri. Seperti yang dikatakan oleh Ketua Dekel Klender di bawah ini:

\begin{abstract}
Perencanaan bina ekonomi sesuai dengan yang telah ditentukan bersama antara Dekel dengan Lurah. Sedangkan untuk masingmasing $R T$ dan $R W$ tergantung proposal yang masuk dari warga. Semakin banyak proposal yang masuk dari suatu $R W$ dan memenuhi persyaratan, semakin banyak pula jumlah masyarakat pemanfaatnya.
\end{abstract} (Sub, Agus 2005).

Hal ini juga diakui oleh TPK/UPK RW 15 Pur (Sep 2005) bahwa perencanaan peminjaman dana bergulir diserahkan langsung ke masyarakat. Masyarakat boleh mengusulkan berapa nilai pinjamannya sesuai dengan jenis usahanya. Kalau masyarakat meminjam lebih dari Rp 5 juta, mereka harus punya angunan. Meskipun masyarakat yang merencanakan proposal peminjaman, pihak Dekel dan TPK RW yang menentukan nilai pinjaman. Jumlah pinjaman masing-masing warga masyarakat berbeda-beda sesuai dengan jenis usahanya dan terlebih dahulu dilakukan survei.

Jadi, pada bina ekonomi masyarakat hanya terlibat pada tahap assessment. Tahap perencanaan ditentukan oleh pihak lain. Hal ini sesuai dengan prosedur yang telah ditentukan, bahwa masyarakat yang bisa meminjam adalah mereka yang telah memenuhi persyaratan. Mereka yang tidak punya KTP tidak bisa berpartisipasi. Begitu juga dengan masyarakat yang miskin dan memiliki KTP tapi tidak punya usaha, mereka juga tidak bisa berpartisipasi. Namun, masyarakat miskin dan ber-KTP ini diberi sedikit kelonggaran kalau ada jaminan dari warga yang lain. Kalau mereka memang ingin 
berusaha, mereka merencanakan usaha yang akan dilaksanakan terlebih dahulu.

Sementara itu, dari segi pemanfaatan dana pinjaman bergulir ini ditemui ada penyimpangan. Ada warga yang menggunakan dana ini untuk keperluan lain, bukan untuk menambah modal. Seperti apa yang telah dilakukan oleh Suy, warga RT/RW 08/03, ia tidak hanya mengunakan dana pinjaman tersebut untuk modal berdagang sayur. Dana tersebut hanya sepertiga yang digunakan untuk penambahan modal, sedangkan selebihnya ia gunakan untuk membeli televisi bekas. Hal ini juga dilakukan oleh Sun (Feb 2006), pedagang nasi uduk, warga RT/RW 07/03. Dana yang ia peroleh dari TPK RW digunakan untuk membayar kontrakan. Alasannya, jumlah uang tersebut cukup banyak sehingga ia gunakan untuk membayar kontrakan. Selama ini ia selalu kesulitan untuk membayar kontrakan yang jumlahnya cukup besar. Alasan lainnya adalah penambahan modal untuk berdagang nasi uduk tidak akan menambah penghasilan karena pembelinya tidak bertambah.

Walaupun ada warga yang memanfaatkan dana tidak sesuai dengan ketentuan, masyarakat yang menggunakan dana sesuai dengan ketentuan atau kesepatan yang dibuat cukup banyak. Menurut warga, ketika dana sudah cair, mereka langsung memanfaatkannya. Mereka menambah barang dagangannya. Semua uang tersebut digunakan untuk meningkatkan dagangannya. Mereka membelanjakan semua uang tersebut ke barang dagangan. Setelah satu bulan, mereka juga harus menyediakan uang untuk mencicil peminjaman. Mereka membayar cicilan setiap awal bulan ke TPK/UPK RW. Jumlah cicilan sesuai dengan jumlah pinjaman dan waktu pengembalian.

"Sayaselalumencicilke Pak Sla setiap bulan. Saya antarkan langsung ke TPK/UPK RW. Saya malu Kalau Pak Sla yang menjemput apalagi kalau sampai menunggak." (Kas, Agus 2005)

Bahkan, ada warga yang malu kalau ada tunggakan. Agar tidak menunggak, mereka menyisihkan uang hasil jual beli setiap hari. Uang yang disisihkan ini nantinya dibayarkan ke TPK/ UPK-nya pada setiap awal bulan.

\begin{abstract}
"Saya sisihkan setiap hari sepuluh ribu sehigga satu bulan sudah terkumpul tiga ratus ribu dan langsung saya setor ke Buk Pur:" (San, Sep 2005)
\end{abstract}

Pada batas waktu yang telah ditetap-kan, mereka melunasi termasuk tunggakan dalam satu bulan. Kalau waktu pengembalian pinjaman yang ditentukan satu tahun, pada bulan ke 12 mereka sudah melunasinya. Mereka pada umumnya melunasi tepat waktu. Kalau pun ada yang menunggak beberapa bulan, mereka tetap melunasinya. Hal itu mereka lakukan karena menjaga kepercayaan dan agar mereka bisa meminjam kembali.

Di Klender, masyarakat banyak menunggu giliran pinjaman bergulir ini. Setiap cicilan mereka lunas, mereka memasukan proposal pijaman lagi.

\section{Saya sudah tiga Kali meminjam. Pinjaman saya pertama lunas, saya langsung memasukan usulan peminjaman lagi. Tahap pertama saya mendapat pinjaman Rp 500 ribu. Tahap dua dan tiga masing-masing dapat Rp I juta. Jadi Kalau saya dapat meminjam, saya meminjam lagi(Kas, Agus 2005).}

Masyarakat berpartisipasi disebabkan oleh beberapa faktor. Faktor pertama adalah mereka bisa meminjam berkali-kali. Dari data yang diperoleh, ada di antara mereka yang sudah tiga kali meminjam dan memasukan proposal pinjaman lagi pada tahun 2005 ini. Alasan kedua, nilai pinjaman (jumlah uang) cukup besar jika dibandingkan dengan meminjam di koperasi. Alasan ketiga, bunga pinjaman cukup rendah jika dibandingkan dengan meminjam ke rentenir. Alasan berikutnya, prosedur peminjaman mudah dan tidak dikenakan sanksi atau denda kalau terjadi penunggakan. Hal ini berbeda kalau mereka meminjam ke bank dan rentenir. Masyarakat yang meminjam di bawah $\mathrm{Rp} 5$ juta tidak perlu memberikan agunan. Alasan terakhir, perasaan malu kalau ditagih oleh TPK, apalagi kalau mendapatkan surat teguran dan didatangi oleh TPK, Dekel, dan lurah.

Jadi, di kelurahan Klender tidak adanya dana yang mengangur. Dana ini setiap bulan digulirkan, setelah pada akhir bulan dikumpulkan dari masyarakat yang menyetor (cicilan masyarakat) 
pada awal bulan ke TPK/UPK RW. Pada tahun 2001, perguliran dan ini bertahap. Jadi, dana ini setiap tahun selalu digulirkan. Meskipun pada tahun 2003 tidak ada dana dari pemerintah DKI Jakarta, Dekel Klender tetap menggulirkan dana ke masyarakat, yaitu dana yang telah terkumpul kembali dari masyarakat.

Sementara itu, di bina ekonomi ini, dana (dana awal ditambah dana guliran) yang telah digulirkan oleh Dewan Kelurahan Klender dari akhir tahun 2001 sampai 2004 berjumlah Rp 3.645.476.000,00 (tiga miliar enam ratus empat puluh lima juta empat ratus tujuh puluh enam ribu rupiah). Sebaliknya, jumlah pemanfaatnya adalah 1.525 orang. Jenis usahanya pun berbeda-beda, seperti klontong, warung nasi, dagang buah, dagang sayuran, dagang kepala dan kulit kambing, kredit pakaian dan alat elektronik, pembuatan gerobak, dan usaha perabotan rumah tangga. Jumlah yang mereka pinjam berfariasi, mulai dari Rp 500 ribu sampai Rp 20 juta. Begitu juga dengan jumlah cicil dan tenggang waktu, masing-masing mereka berbeda. Lama waktu pengembalian ada sepuluh bulan, setahun dan delapan belas bulan(2001-2002). Namun berdasarkan peraturan terbaru, lama pengembalian maksimal satu tahun. Masyarakat pemanfaat yang meminjam lebih dari Rp 5 juta harus memakai agunan atau jaminan.

Sejak tahun 2003, berdasarkan himbauan Walikota Jakarta Timur, agar masyarakat tidak mengalami kesulitan dalam pembayaran pinjaman dana bergulir, Dekel Klendermewajibkan masyarakat pemanfaat untuk masuk asuransi. Asuransi yang bekerja sama dengan Dekel Klender adalah Asuransi Bumi Putra. Umur maksimum yang boleh masuk asuransi adalah 60 tahun. Tujuannya adalah apabila masyarakat pemanfaat mengalami kecelakaan sehingga lumpuh dan tidak bisa berusaha, atau yang bersangkutan meninggal dunia, sementara waktu pengembalian masih berjalan, sisa pengembalian sesuai dengan kesepakatan akan diganti oleh pihak asuransi. Jadi, anggota keluarga yang ditinggalkan tidak mesti menanggung pengembalian dana yang dipinjam tersebut.

Masyarakat pun tidak keberatan mengenai adanya asuransi ini. Mereka menerima karena jumlahnya tidak terlalu besar. Selama penelitian, mereka tidak ada yang mengeluh mengenai asuransi ini.

\section{Gambaran Partisipasi Masyarakatpada Tahap Evaluasi}

Menurut Sla, TPK/UPK RW 03 Untuk bina ekonomi, ia setiap bulan menyetorkan uang cicilan dari masyarakat dan mengambil dana dari UPK Dekel untuk diberikan ke warga. Selain itu, ia juga harus membuat laporan bulanan ke Dekel. Diakuinya juga bahwa ia tidak terlibat dalam evaluasi. Namun, pihak TPK dilibatkan pada saat monitoring, seperti monitoring pelaksanaan pembangunan bina fisik.

Sementara itu, menurut Ketua Dekel Sub, pihaknya membuat laporan ke Lurah dan BPM Kota Jakarta Timur berdasarkan laporan yang masuk dari TPK/UPK RW dan hasil monitoring ke lapangan, seperti laporan untuk bina ekonomi yang ada tunggakan. Dekel melakukan monitoring ke sana. Sehingga apa yang dilaporkan TPK/UPK dapat dibuktikan dan ditindaklanjuti. Warga juga mengakui bahwa mereka tidak dilibatkan dalam monitoring dan evaluasi kegiatan. Hal ini membuat mereka tidak tahu hasil dari penerapan PPMK di Kelurahan Klender.

\section{Persentase Partisipasi Masyarakat dalam PPMK}

Dari hasil penghitungan, ternyata, persentase partisipasi masyarakat lebih tinggi pada tahap pelaksanaan. Persetase pada tahap plaksaaan paling tinggi ada pada bidang ekonomi, yakni 18 orang dari 25 orang warga yang diwawancarai atau $72 \%$. Pada tahap yang sama, urutan kedua pada bidang fisik, yakni $20 \%$ dan ketiga sosial 4\%. Pada tahap assessmen, persentase partisipasi masyarakat sama pada ketiga bina, yakni delapan persen. Sementara itu, pada tahap perencanaan dan evaluasi, tidak ada partisipasi masyarakat. Untuk lebih jelasnya, partisipasi masyarakat pada keempat tahap dapat

Tabel 4 Partisipasi Warga Pada tahap Assessment, Perencanaan, Pelaksanaan dan Evaluasi

\begin{tabular}{lcccc}
\hline Nama Bina & Asessment & $\begin{array}{c}\text { per- } \\
\text { enc- } \\
\text { naan }\end{array}$ & pelaksanaan & evalasi \\
\hline Bina Fisik & 2 & - & 10 & - \\
Bina & 2 & - & 18 & - \\
Ekonomi & 2 & - & 1 & - \\
Bina Sosial & 2 & & & \\
\hline
\end{tabular}


dilihat dari tabel di bawah ini.

\section{Kesimpulan}

Peranan masyarakat dalam menyukseskan PPMK di Kelurahan Klender tidak hanya pada satu tahap saja tetapi pada setiap tahap (proses) dalam PPMK. Hal ini sesuai dengan apa yang dikatakan Adi bahwa untuk melihat partisipasi masyarakat desa dalam pembangunan adalah pada empat tahap, yakni: partisipasi dalam tahap assessment, perencanaan, pelaksanaan dan partisipasi dalam tahap evaluasi. Begitu juga halnya dengan partisipasi yang ditekankan dalam prinsip PPMK, yaitu: perencanaan, pelaksanaan dan pengawasan. Assessment tidak ada pada tahun 2001, karena program ini baru dilaksanakan pada tahun 2002 untuk bina sosial dan fisik. Begitu juga dengan bina ekonomi, assessment tidak ada, meskipun bina ini telah dilaksanakan pada November 2001. Peranan masyarakat yang besar hanyalah pada tahap assessment dan pelaksanaan pada tahun 2002, 2004 dan 2005. Hal ini terlihat pada ketiga bina yang dilaksanakan dalam PPMK, yaitu: bina sosial, fisik dan ekonomi. Pada tahap perencanaan, peranan masyarakat hanya ada pada dua bina saja, yaitu: sosial dan fisik. Sebaliknnya, pada bina ekonomi, masyarakat tidak dilibatkan dalam perencanaan, sejak bina ekonomi dilaksanakan tahun 2001 sampai 2005. Semua perencanaan bina ekonomi sudah ada dan diatur oleh pemerintah dan teknisnya dipersiapkan oleh Dekel. Pada bina ekonomi masyarakat tinggal menerima apa yang telah diputuskan oleh pemerintah dan dipersiapkan oleh Dekel. Pada tahap evaluasi, partisipasi masyarakat tidak ada sama sekali setelah satu tahun berjalannya PPMK, yaitu dari tahun 2002-2005. Pada tahap terakhir ini, berdasarkan pedoman pelaksanaan PPMK tahun 2003-2007, pada bagian tugas-tugas unit pelaksana PPMK di Provinsi DKI, unit yang bertugas dalam evaluasi dan pemantauan kegiatan PPKK hanyalah Badan Pemberdayaan Masyarakat (BPM) Kota dan LSM pendamping yang telah dikontrak. Sementara itu, Dekel memberikan laporan bulanan dan tahunan ke BPM Kota dan Lurah berdasarkan hasil monitoring yang telah dilakukannya dan laporan bulanan dari TPK/ UPK. Partisipasi masyarakat pun dilakukan secara langsung dan perwakilan. Pada tahap assessment misalnya, masyarakat langsung berpartisipasi pada pertemuan bulanan RT. Sedangkan pada pertemuan tingkat RW dan forum warga, partisipasi masyarakat sudah dengan sistem keterwakilan, yakni melalui utusan RT-nya masing-masing.

Partisipasi masyarakat yang tidak dengan keterwakilan adalah pada tahap pelaksanaan. Pada ketiga bina tersebut, masyarakat berperan langsung. Hal ini bisa dilihat satu per satu. Di bina ekonomi, masyarakat menjadi pemanfaat dana bergulir dan mengembalikan dana sesuai dengan kesepatan yang telah dibuat. Masyarakat menjadi peserta dan instruktur pada pelaksanaan kursus (bina sosial). Begitu juga dengan pelaksanaan bina fisik, masyarakat berperan serta. Partisipasi masyarakat pada tahap pelaksanaan bina fisik berupa tenaga, makanan kecil, peminjaman lahan dan alat-alat pertukangan yang dibutuhkan. Pelaksanaan program tidak saling ter-integrasi, yaitu sendiri-sendiri Contohnya, masyarakat yang telah ikut pelatihan (kursus) tidak semuanya diberikan bantuan modal untuk membuka usaha. Pemberian batuan modal kepada masyarakat peserta kursus tidak direncanakan dari awal, hanya kebetulan saja ada beberapa orang peserta kursus yang mendapatkan modal untuk membuka usaha.

\section{Daftar Pustaka}

Adi, Isbandi Rukminto. 2003. Pemberdayaan, Pengembangan Masyarakat dan Intervensi Komunitas. Jakarta: Lembaga Penerbit Fakultas Ekonomi Universitas Indonesia.

Chandra, Eka. 2002. Penguatan masyarakat sipil dalam konteks hubungan kekuatan dan kerterwakilan studi kasus terhadap forum masyarakat Majalaya Sejahtera. Di dalam Analisis Sosial. Vol 7.No 2. hal. 110-140.

Kusuma, H. Soni. 2002. Membangun institusi warga untuk menanggulangi kemiskinan masyarakat dan kelembagaan lokal pengalaman kasus P2KP. Di dalam Analisis Sosial. Vol 7.No 2. hal. 169-186.

Widodo, M. Agung. 2002. Program Pengembangan Kecamatan (PPK) menanggulangi kemiskinan melalui penguatan pastisipasi masyarakat dan kelembagaan lokal. Di dalam Analisis Sosial. Vol 7.No 2. hal. 155-168.

[Kompas]. 2005. Profil kemiskinan ibu kota. 
Kompas Cyber Media (KCM) Kamis, 21 April. Hasibuan, Fince D. 2003. Jenjang partisipasi masyarakat dalam perencanaan pembangunan melalui Forum Komunikasi Perencana Pembangunan di Kota Depok. Tesis. Program Pascasarjana Kesejahteraan Sosial. UI.

Jhonopa. 2004. Partisipasi masyarakat dalam penyusunan program pembangunan nagari, studi kasus di Kenagarian Singkarak Kecamatan X Koto Singkarak Kecamatan Solok. Tesis. Program Pascasarjana Kesejahteraan Sosial UI.

Junaidi. 2004. Pemberdayaan masyarakat melalui Program Pengembangan Kecamatan (PKK) fase II: studi kasus Desa Gosong Talaga Selatan, Kecamatan Singkil Utara, Kabupaten Aceh Singkil. Tesis. Program Pascasarjana Kesejahteraan Sosial UI.

Mikkelsen, Britha. 1999. Metoda Penelitian Partisipasi dan Upaya-Upaya Pemberdayaan. Jakarta: Yayasan Obor.

Moleong, Lexy. 1998. Metodologi Penelitian Kualitatif. Bandung: PT Remaja Rosdakarya.

Slamet, Y. 1993. Pembangunan Masyarakat Berwawasan Partisipatif. Surakarta: Sebelas Maret University Press.

Widiantoro, Heru. 2003. Kajian Proyek Penanggulangan Kemiskinan di Perkotaan (P2KP). studi kasus pelaksanaan P2KP di Kelurahan Condong Catur, Kecamatan Depok, Kabupaten Sleman, Propinsi Daerah Istimewa Yogyakarta. Tesis. Program Pascasarjana Kesejahteraan Sosial UI.

Zulhaeni. 2003. Partisipasi perempuan dalam Forum Warga: studi tentang partisipasi perempuan dalam perencanaan dan pelaksanaan kegiatan melalui Forum Komunitas RT, RW Kelurahan Pal Merah, Jakarta Barat. Tesis. Program Pascasarjana Kesejahteraan UI. 